\title{
STRATEGI KOMUNIKASI BSIS MELALUI EDUKASI PENGELOLAAN SAMPAH UNTUK PENCEGAHAN PENYEBARAN PENYAKIT DI MASA PANDEMI COVID-19
}

\author{
Lisa Indriati $^{1 *}$, Paulina Tjandrawibawa ${ }^{2}$, Mychael Maoretz Engel ${ }^{3}$ \\ ${ }^{1}$ Desain Komunikasi Visual, Universitas Ciputra, Surabaya, Indonesia \\ *Email: lisa.indriati@ciputra.ac.id
}

\begin{abstract}
Informasi Artikel
Abstrak

Kata kunci :

Pengelolaan sampah,

nilai sampah,

pandemi,

limbah masker

Diterima: 13-01-2021

Disetujui: 22-04-2021

Dipubikasikan: 14-07-

2021

Menurut data dari Kementrian Lingkungan Hidup dan Kehutanan (KLHK), jumlah sampah di Indonesia akan terus meningkat hingga 95,2 juta ton pada tahun 2020. Sebagai salah satu solusi pemecahan permasalahan sampah ini, dibentuklah Bank Sampah Induk Surabaya (BSIS). Namun, masih banyak masyarakat yang belum menyadari manfaat dan cara mengelola sampah yang benar. Mereka juga memiliki persepsi bahwa BSIS bukanlah organisasi non-profit.Dengan adanya pandemi Covid 19 BSIS juga mengalami hambatan dalam melakukan kegiatan sosialisasi. Oleh sebab itu, mempertimbangkan situasi yang dialami saat ini ada beberapa solusi dan metode yang ditawarkan pada Program Kemitraan Masyarakat ini antara lain (1) Sosialisasi mengenai manfaat dan langkah-langkah pemilahan sampah; (2) Pengadaan modul dan webinar edukasi pengelolaan sampah dalam upaya pencegahan penyakit di masa pandemi Covid; (3) Brosur jenis-jenis sampah yang dapat diolah oleh BSIS beserta nilai ekonomis yang ditawarkan; dan (4) Media komunikasi BSIS berupa website dan media sosial. Masyarakat yang menjadi peserta dalam webinar sosialisasi dan edukasi memberi respon yang positif dan berinisiatif untuk mencoba menerapkan pemilahan sampah. Dengan adanya brosur, website dan media sosial, diharapkan pihak BSIS mampu melanjutkan kegiatan sosialisas atau edukasi tentang pengelolaan sampah dalam upaya pencegahan penyakit di masa pandemi Covid secara mandiri.
\end{abstract}

Keywords :

Waste Management,

Trash Value, Pandemic, Mask Waste
According to data from the Ministry of Environment and Forestry (KLHK), the amount of waste in Indonesia will continue to increase to 95.2 million tons by 2020. As one solution to this waste problem, Bank Sampah Induk Surabaya (BSIS) was formed. However, there are still many people who do not realize the benefits and ways of managing waste properly. They also have the perception that BSIS is a non-profit organization. With the Covid19 pandemic BSIS also experienced obstacles in carrying out socialization activities. Therefore, considering the appropriate situation at this time, there 
are several solutions and methods offered in the Community Partnership Program, including (1) Socialization of the benefits and steps for sorting waste; (2) Procurement of waste management educational modules and webinars in an effort to prevent disease during the Covid pandemic; (3) Types of waste that can be processed by BSIS along with the economic value offered; and (4) BSIS communication media in the form of websites and social media. People who participated in the socialization and education webinars gave positive responses and took the initiative to try to implement waste sorting. Expectedly BSIS will be able to continue socialization or education activities on waste management in an effort to independently prevent disease during the Covid pandemic with the existence of brochures, websites and social media.

\section{PENDAHULUAN}

Pengelolaan sampah di Indonesia ini masih menjadi masalah besar di Indonesia, menurut data dari Kementrian Lingkungan Hidup dan Kehutanan (KLHK) pada tahun 2019 total sampah di Indonesia mencapai 68 juta ton dan diperkirakan akan meningkat hingga 95,2 juta ton pada tahun 2020. Jumlah sampah yang terus meningkat ini mengakibatkan dampak buruk ke lingkungan, seperti longsor yang terjadi di Tempat Pembuangan Akhir (TPA) Leuwigajah pada bulan Februari 2005 silam, sebanyak 157 orang tewas tertimbun longsoran sampah. Kasus lain juga terjadi di Pekanbaru, banjir karena hujan deras (Syukur, 2017). Juga ada kejadian terjadi banjir di kota Bogor akibat banyak sampah yang tidak dibuang pada tempatnya dan di daur ulang (Sudarno, 2017). Kesadaran masyarakat untuk membuang sampah pada tempatnya masih minim, sampai walikota Surabaya, Risma, menyatakan ingin membantu Indonesia untuk bebas dari sampah (Kurniawan, 2019).

Kepedulian terhadap masalah pengelolaan sampah ini, Yayasan Bank Sampah Induk Surabaya (BSIS) hadir sebagai salah satu solusi untuk masalah pembuangan sampah sembarangan yang terjadi di Surabaya. BSIS dibentuk karena keinginan untuk memotivasi masyarakat melakukan program pemerintah Indonesia dalam mengurangi limbah dengan menggunakan prinsip 3R: Reduce, Reuse, Recycle (Faizal et all, 2018). Reduce adalah dengan mengurangi pemakaian barang-barang dari plastik terutama yang sekali pakai, Reuse menggunakan kembali barang-barang yang masih berfungsi dan terutama yang terbuat dari plastik, dan Recycle adalah mendaur ulang barang-barang (Purwaningrum, 2016).

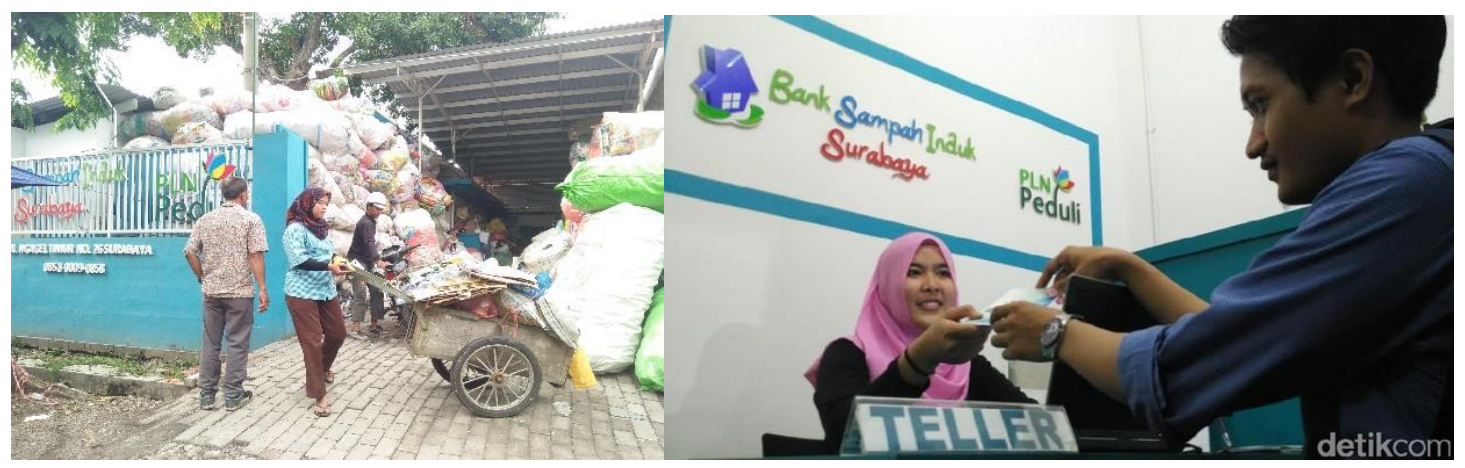


Gambar 1. Kantor Bank Sampah Induk Surabaya

BSIS berdiri pada tanggal 3 Oktober 2010, dan bertujuan untuk mengedukasi masyarakat tentang kegiatan pemilahan sampah serta menjadikan sampah menjadi barang yang bernilai ekonomis. Sampai saat ini, BSIS dapat menerima 53 jenis sampah yang dapat diolah dan didistribusikan kembali pada industri-industri yang membutuhkan, antara lain: botol plastik, kertas, kardus, kaleng, dan lain sebagainya. Sampah-sampah anorganik yang disetorkan ke BSIS dapat dirupakan dalam bentuk tabungan yang dapat ditukarkan dalam bentuk voucher program atau bisa diambil secara tunai.

Dalam UU No.18 tahun 2008 tentang Pengelolaan Sampah pada pasal 14 dan 15 dijelaskan bahwa sebagai produsen juga memiliki peran sebagai motivator masyarakat untuk membuang sampah pada tempatnya dan belajar untuk mendaur ulang. BSIS memiliki tujuan untuk membangun kesadaran masyarakat tentang masalah sampah dan terus mendorong juga memotivasi agar masyarakat berubah menjadi lebih baik. Salah satu cara untuk membangun kesadaran masyarakat mengenai sampah adalah dengan mengedukasi masyarakat akan permasalahan lingkungan yang telah timbul dan bersifat kompleks karena banyaknya timbunan sampah (Asteria dan Heruman, 2015). Selama ini, BSIS giat melakukan penyuluhan ke daerah pemukiman agar masyarakat sadar bahwa barang anorganik bisa didaur ulang dan memberikan nilai ekonomis yang dapat membantu perekonomian rumah tangga.

Selama ini persepsi masyarakat terhadap BSIS adalah sebuah perusahaan yang bergerak pada jasa pemilahan sampah, padahal BSIS adalah organisasi non-profit yang bertujuan untuk membantu lingkungan Surabaya menjadi lebih bersih melalui program pemilahan sampah. Karena persepsi masyarakat yang salah ini, seringkali BSIS mengalami kesulitan dalam melakukan sosialisasi kepada masyarakat. Media informasi BSIS yang ada saat ini juga belum cukup dalam memberikan edukasi pada masyarakat tentang visi dan misi serta tujuan yang sebenarnya didirikan BSIS ini. Permasalahan ini berdampak pada efektifitas BSIS dalam melakukan kampanye program-program yang ada, sehingga diperlukan sebuah media komunikasi yang sesuai dengan kebutuhan BSIS untuk mengomunikasikan brand mereka pada masyarakat Surabaya. Media komunikasi memiliki peran penting agar sebuah perusahaan atau organisasi tidak gagal dalam melakukan branding untuk poduk atau jasa yang dimiliki (Marta \& Havifi, 2017). 

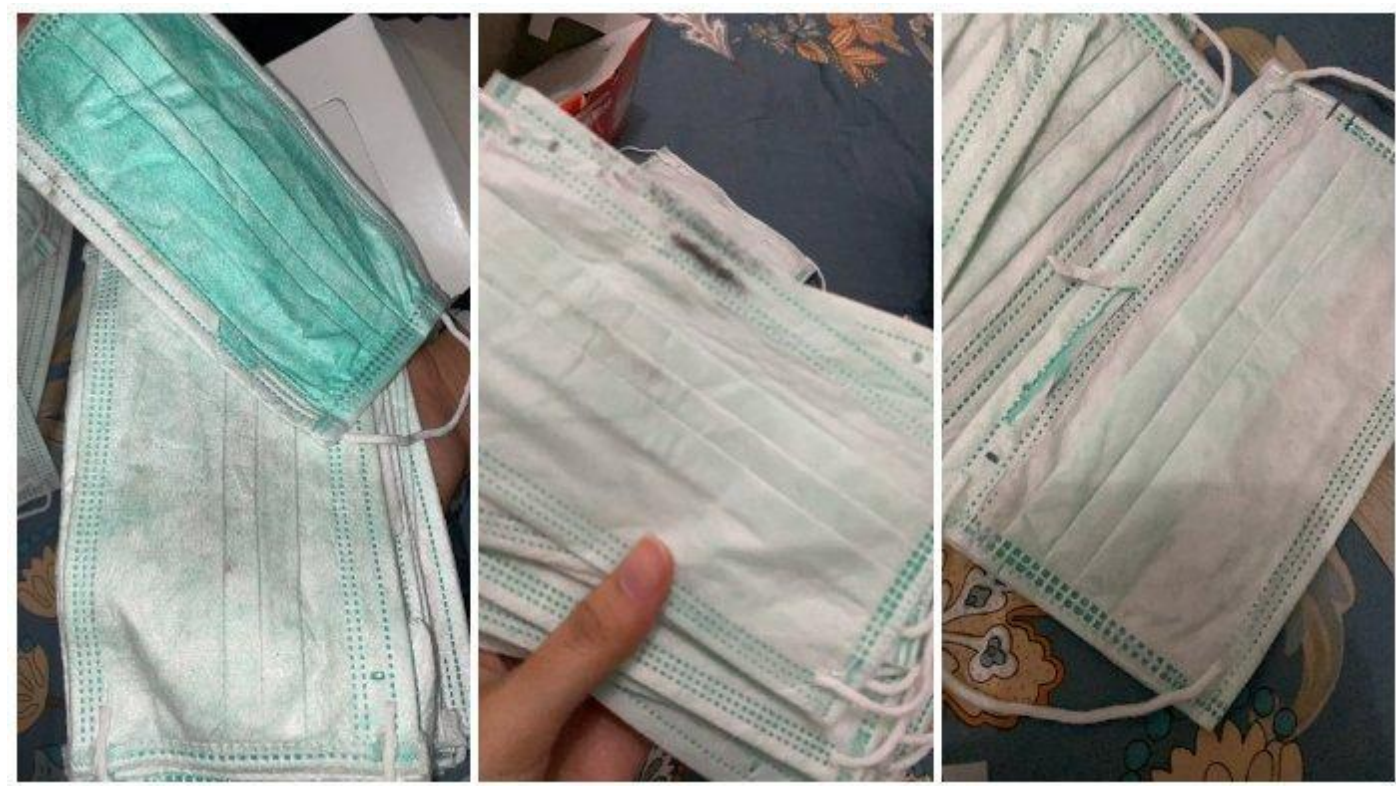

Gambar 2. Masker bekas yang dikemas ulang dan diperjualbelikan

Pandemi Covid juga menjadi darurat kesehatan global yang dideklarasikan oleh WHO pada 30 Januari 2020 (Saadat, 2020). Mudahnya penyebaran virus ini membuat orang memakai masker sebagai tindakan pencegahan, menggunakan sarung tangan dan pembersih tangan setiap hari yang menghasilkan limbah medis dalam jumlah besar di lingkungan. Pandemi ini juga telah mengubah gaya hidup masyarakat, menjadikan masker dan sarung tangan plastik kebutuhan sehari-hari; namun, belum banyak yang yang mengetahui cara yang benar saat membuang limbah masker sekali pakai. Bahkan akibat kelalaian ini, pada bulan April 2020, sempat terjadi penjualan masker bekas yang dikemas ulang seolah-olah produk baru (republika.co.id). Perkumpulan Ahli Lingkungan Indonesia (Indonesia Environmental Scientists Asscociation/IESA) juga memperingatkan akan terjadi penambahan limbah infeksius di tengah pandemi Covid yang didasarkan pada studi kasus data dari China. Penambahan limbah medis yang terjadi dari 4.902,8-ton menjadi 6.066 ton per hari. Hal ini pun bisa terjadi di Indonesia seiring bertambahnya kasus Covid.

Berdasarkan hal-hal tersebut, BSIS berupaya untuk mengajak masyarakat lebih sadar dan tetap peduli lingkungan. Namun, masa pandemi Covid ini menghambat kegiatan sosialisasi yang biasa dilakukan oleh BSIS secara tradisional yaitu melalui kunjungan ke desa-desa di Surabaya, sehingga diperlukan media komunikasi baru dalam mengomunikasikan program BSIS mengenai pengelolaan sampah dalam upaya pencegahan penyakit di masa pandemi Covid.

Dari hasil analisis permasalahan BSIS sebagai mitra, ada dua kelompok masalah utama yaitu: kesadaran pengelolaan sampah dan persepsi masyarakat tentang BSIS yang bukan merupakan organisasi non-profit. Untuk kesadaran pengelolaan sampah ada empat poin yang diangkat yaitu (a) masyarakat belum peduli dengan manfaat pemilahan sampah (b) Masyarakat belum mengetahui 
manfaat pengelolaan sampah dalam upaya pencegahan Covid (c) Masyarakat belum mengetahui cara yang benar untuk membuang masker dan sarung tangan sekali pakai (d) Masyarakat belum mengetahui bahwa sampah dapat memberikan nilai ekonomi. Sedangkan untuk permasalahan tentang persepsi masyarakat tentang BSIS bukan sebagai organisasi non-profit perlu diadakan media komunikasi berupa website dan media sosial.

\section{METODE}

Rincian metode pendekatan PKM kepada mitra dijabarkan seara detail sebagai berikut: Masalah:

a. Masyarakat belum peduli dengan manfaat pemilahan sampah

b. Masyarakat belum mengetahui manfaat pengelolaan sampah dalam upaya pencegahan Covid

c. Masyarakat belum mengetahui cara yang benar untuk membuang masker dan sarung tangan sekali pakai

d. Masyarakat belum mengetahui bahwa sampah dapat memberikan nilai ekonomi

e. Persepsi masyarakat tentang BSIS bukan sebagai organisasi non-profit

Solusi:

a. Sosialisasi mengenai manfaat dan langkah-langkah pemilahan sampah

b. Pengadaan webinar edukasi pengeloaan sampah dalam upaya pencegahan penyakit di masa pandemi Covid

c. Memberikan edukasi mengenai tata cara mengelola sampah untuk mencegah penyebaran penyakit

d. Brosur jenis-jenis sampah yang dapat diolah oleh BSIS berserta nilai ekonomi yang ditawarkan

e. Media komunikasi BSIS berupa website dan media sosial

Metode:

a. Sosialisasi online melalui melalui aplikasi online meeting

b. Diskusi dengan ekspert dan pihak BSIS untuk merancang materi webinar

c. Koordinasi dengan ekspert di bidang kesehatan masyarakat

d. Koordinasi dengan BSIS dan tim layouter brosur

e. Koordinasi dengan BSIS dan tim web development

f. Koordinasi dengan tim desain media komunikasi

Prosedur Kerja:

a. Bekerjasama dengan ketua RT/RW setempat

b. Melakukan promosi acara sosialisasi melalui media sosial dan email blast

c. Meeting koordinasi antar tim pengusul dan pihak BSIS

d. Melakukan perancangan materi webinar

e. Menghubungi ekspert di bidang kesehatan masyarakat

f. Melakukan finalisasi layout 
g. Membimbing tim web development untuk finalisasi website

h. Membimbing tim desain untuk pembuatan media komunikasi online dan offline

\section{HASIL DAN PEMBAHASAN}

Kegiatan PKM ini telah menghasilkan beberapa luaran diatantaranya:

\section{A. Pembuatan materi dan modul sosialisasi}

Materi sosialisasi program terkait kesehatan dibuat atas hasil kerjasama dan koordinasi tim pengusul dan dr. Eric Dino Tandoyo yang merupakan dosen Fakultas Kedokteran Universitas Ciputra. Materi yang dibuat berjudul Pengelolaan Limbah Sampah Masker menjelaskan hal-hal berikut ini:

- Overview mengenai peningkatan limbah masker yang terjadi karena pandemi Covid-19

- Pengelolaan limbah APD secara baik dan benar

- Pembuatan disinfektan mandiri di rumah dengan menggunakan bahan-bahan yang tersedia di rumah

- Pengelolaan limbah sampah masker

Untuk materi terkait sosialisasi BSIS dibawakan oleh Bapak Anjar Putro Wiliasmoro, S.Kom.I, selaku ketua BSIS dengan detail materi sebagai berikut:

- Overview tentang pengenalan potensi sampah

- Cara memilah sampah

- Prosedur penyetoran sampah terpilih ke bank sampah

- Sosialisasi mengenai kesadaran dan kebiasaan baik mengelola sampah.

\section{B. Pembuatan website dan media sosial BSIS}

Pembuatan website BSIS merupakan hasil koordinasi rutin tim pengusul dan tim BSIS yang diagendakan setiap hari Jum'at pukul 10.00 - 11.00 WIB. Dalam rapat koordinasi tersebut, pihak BSIS memberikan feedback terkait UI/UX dari website yang telah dibuat oleh tim pengusul. Selain itu, tim pengusul juga memberikan rekomendasi terbaik untuk kemudahan akses menumenu pada website sehingga pengunjung bisa mendapatkan informasi yang dibutuhkan dengan efisien. Website BSIS dapat diakses melalui www.banksampahinduksurabaya.com 


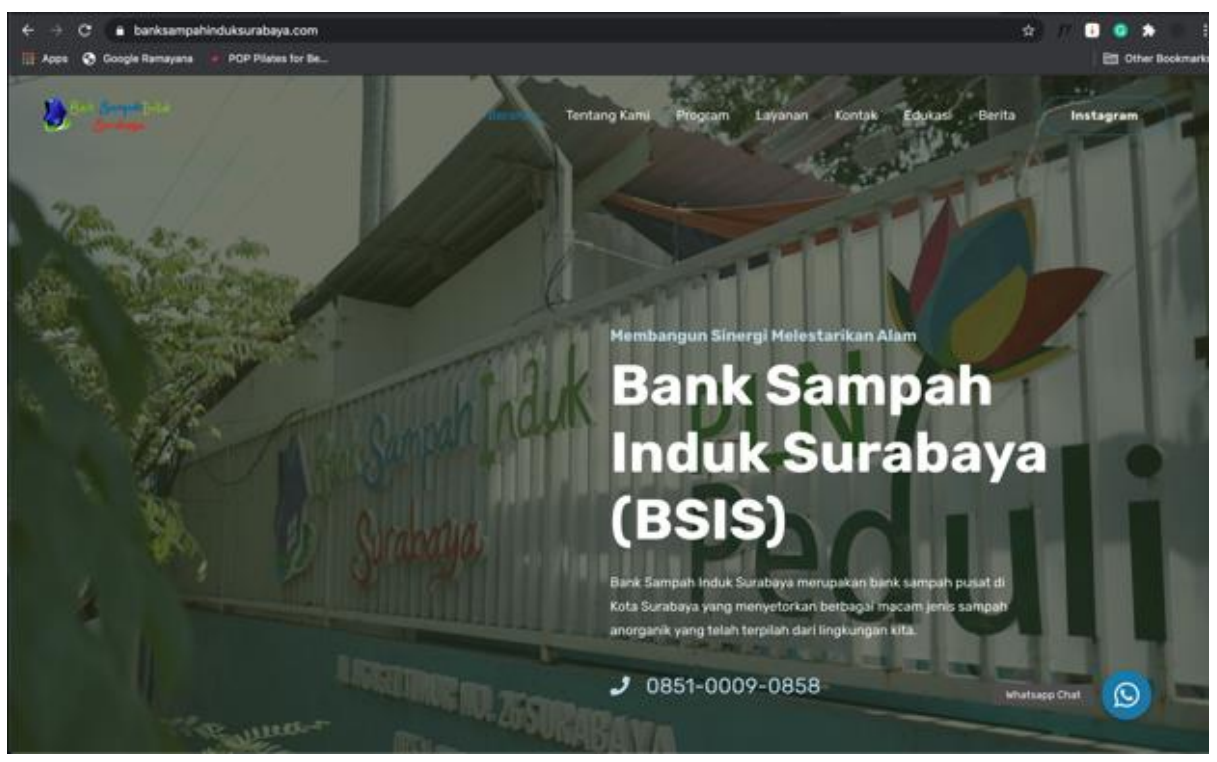

Gambar 3. Tampilan beranda website BSIS
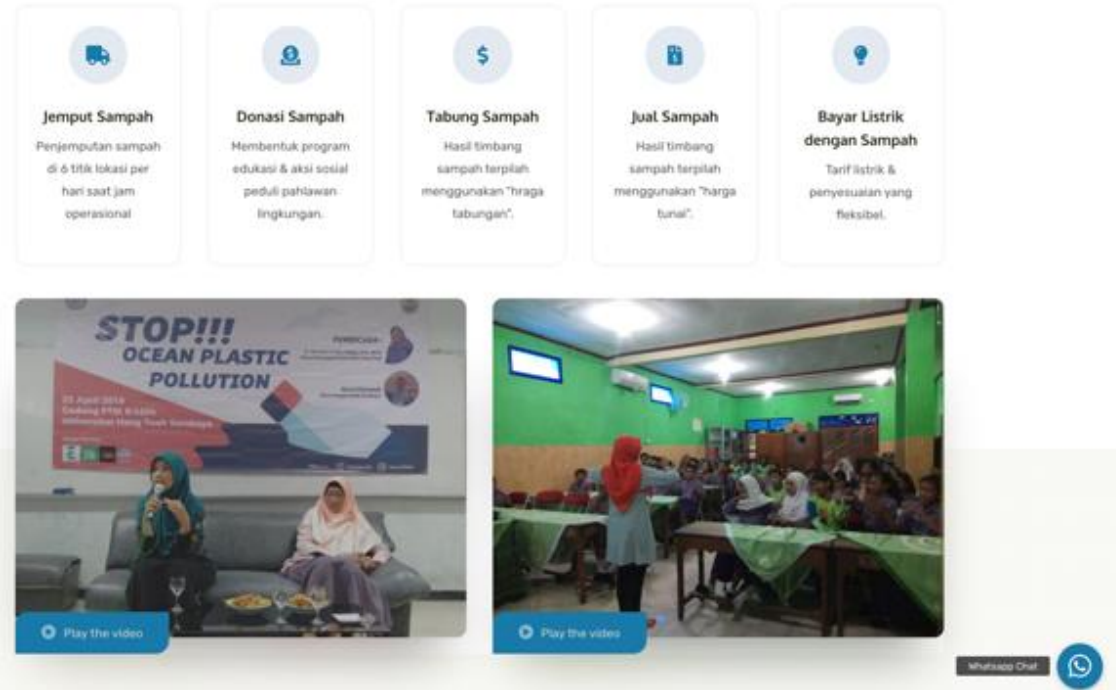

Gambar 4. Tampilan menu website BSIS

Untuk media sosial BSIS telah ada dan cukup aktif melalui Instagram, sehingga tim pengusul hanya membantu mengisi konten terkait program PKM ini. 


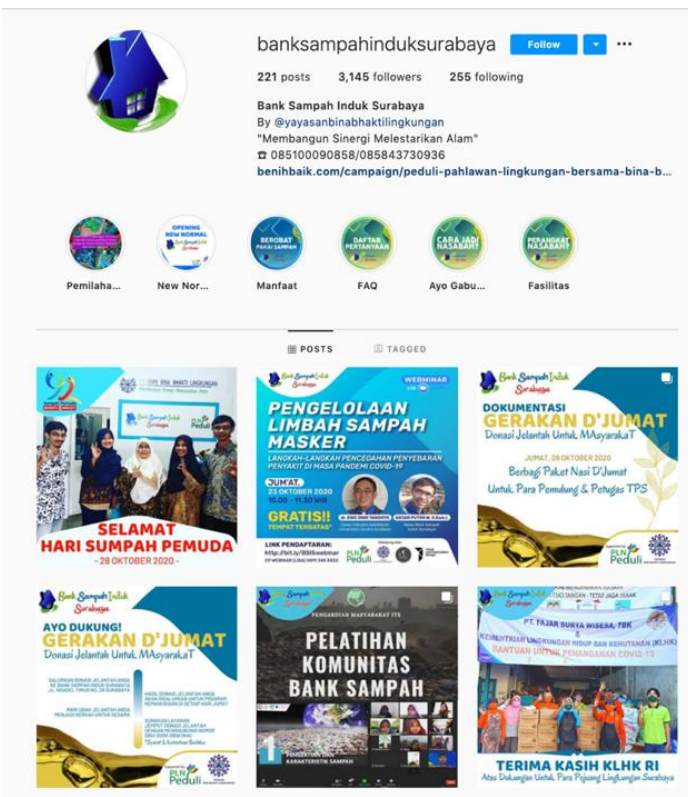

Gambar 5. Instagram BSIS

\section{Pembuatan media komunikasi online dan offline}

Pembuatan media komunikasi online dan offline, antara lain berupa brosur digital terkait kegiatan webinar, daftar 55 jenis sampah yang dapat dikelola oleh BSIS beserta harga yang dibuat versi digital untuk di download serta versi cetak telah disiapkan.

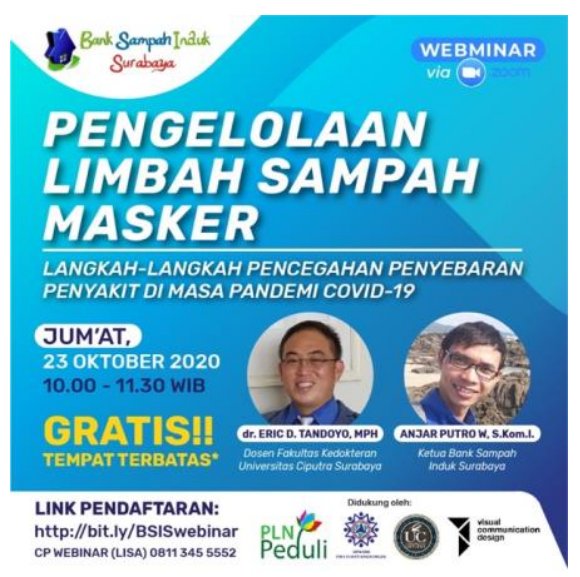

Gambar 6. Poster digital kegiatan webinar bersama dr. Eric Dino Tandoyo, MPH

\section{Pengadaan kegiatan sosialisasi melalui webinar}

Jumlah peserta webinar yang hadir secara live melalui Zoom adalah sebanyak 32 orang dari target 28 peserta. Materi yang dibawakan telah direkam untuk kemudian di posting di media sosial BSIS sehingga dapat menjangkau lebih banyak masyarakat. 


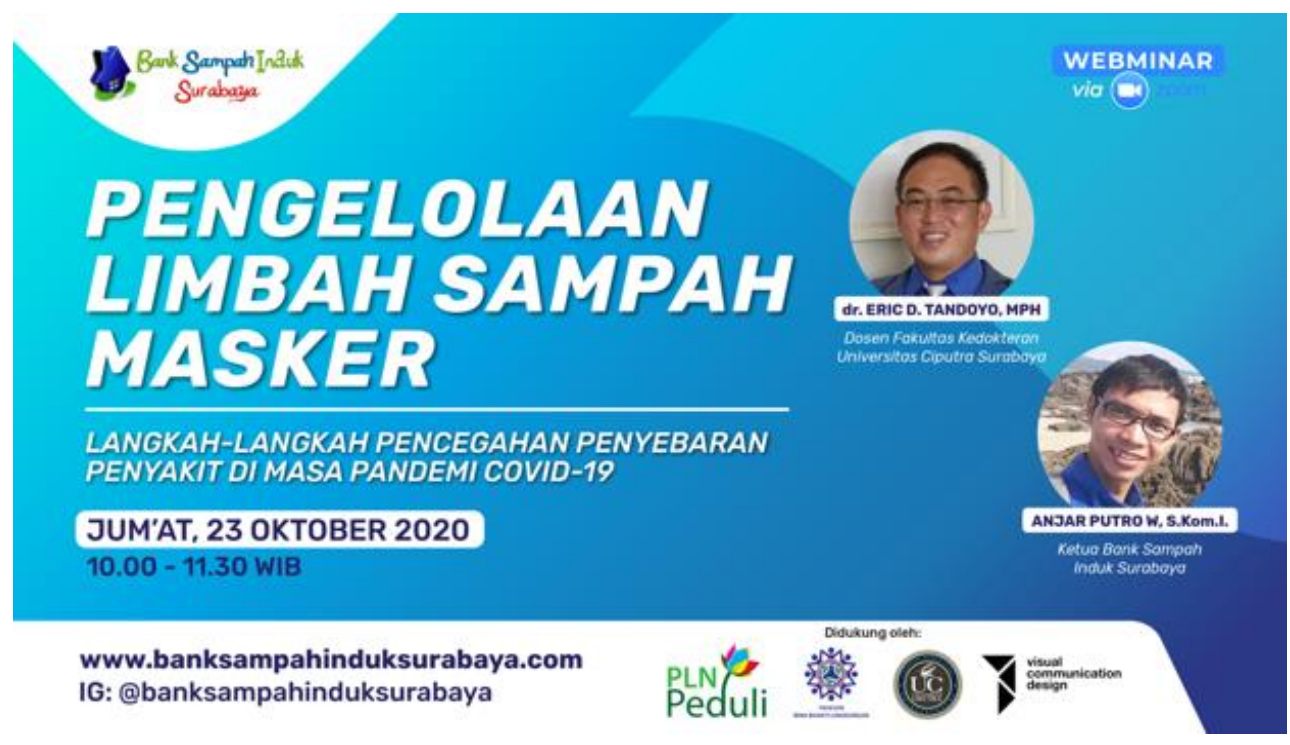

Gambar 7. Poster Kegiatan webinar
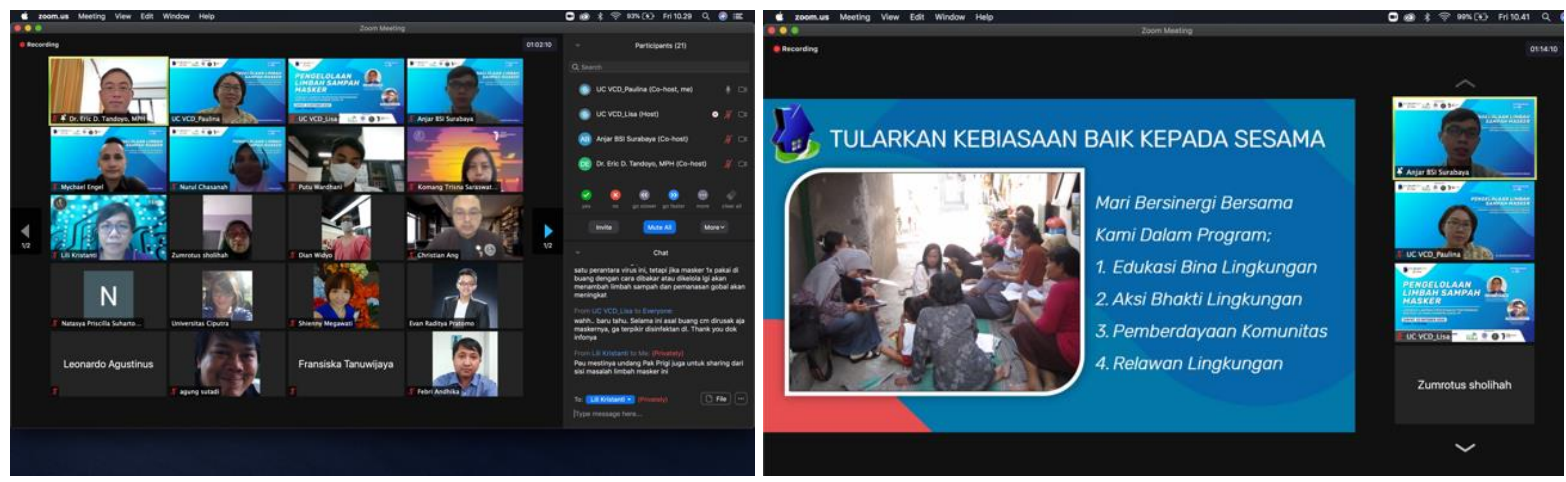

Gambar 8. Kegiatan webinar

\section{E. Pengurusan sertifikat KI untuk media-media yang telah dibuat}

Luaran dari program PKM ini akan didaftarkan pengurusan sertifikat Hak Cipta untuk Poster Digital dan Website. Kedepannya asset-aset yang dihasilkan dalam kegiatan pengabdian ini dapat didaftarkan KI seperti seperti media edukasi BSIS dalam bentuk brosur, materi dan video edukasi.

\section{KESIMPULAN}

Kegiatan PKM ini dapat membantu memberikan manfaat bagi BSIS untuk mengatasi dua permasalahan utama dalam program ini yaitu mengenai kesadaran masyarakat terhadap pengelolaan sampah serta persepsi masyarakat tentang BSIS sebagai organisasi non-profit. Dari hasil feedback yang didapatkan selama melakukan sosialisasi, masyarakat masih awam dengan keberadaan BSIS dan merasa sangat terbantu ketika mendapatkan informasi melalui website. Dengan demikian, program lanjutan yang akan dilakukan oleh pihak BSIS adalah launching website final secara mandiri kepada komunitas binaan serta masyarakat umum. 


\section{UCAPAN TERIMAKASIH}

Penulis mengucapkan terima kasih kepada Lembaga Penelitian dan Pengabdian Masyarakat (LPPM) Universitas Ciputra Surabaya yang telah memberi dukungan finansial terhadap pengabdian ini.

\section{DAFTAR PUSTAKA}

$\begin{array}{llll}\text { Tasikmalaya. Manusia } & \text { dan } & \text { Lingkungan. } & \text { 23(1), }\end{array}$ https://jurnal.ugm.ac.id/JML/article/view/18783/12114.

Daerah, B (2020). Bagian Administrasi Pemerintahan dan Otonomi Daerah. Retreived 14 march 2020, from https://pemerintahan.surabaya.go.id/home/kecamatan kelurahan

Farizal, F., Aji, R., Rachman, A., Nasruddin, N., \& Mahlia, T.M.I. (2018). Indonesia's Municipal Solid Waste 3R and Waste to Energy Programs. Makara Journal of Technology, 21(3), 153-159. doi:10.7454/mst.v21i3.3536.

Kami, T. (2020). Tentang Bank Sampah Induk Surabaya. Retrieved 25 February 2020, from https://banksampahinduksurabaya.blogspot.com/2019/02/tentang-bank- sampah.html

Marta, R. \& Havifi, I. (2017). Media Komunikasi Dalam Branding Pariwisata Kota Padang. Prosiding Konferensi Nasional Komunikasi, Indonesia.1(1). file:///C:/Users/user/Downloads/89-115-1-PB.pdf - blm dapet DOI

Media, K. (2020). Media, K. (2020). Leuwigajah, Kami Takkan Lupa... Retrieved 25 February 2020, from https://regional.kompas.com/read/2011/02/21/20382467/Leuwigajah.Kami.Takka n.\%20Lupa

Purwaningrum, P. (2016). Upaya Mengurangi Timbulan Sampah Plastik di Lingkungan. Indonesian Journal of Urban and Environmental Technology. 8(2), 141-147. http://dx.doi.org/10.25105/urbanenvirotech.v8i2.1421

Republika (2020). Limbah Masker Polusi Bari di Tengah Pandemi. Retrieved 23 April 2020, from republika.co.id/berita/q9710n459/ limbah-masker-polusi-baru-di-tengahpandemi

Risma Ingin Indonesia Bebas Sampah. (2020). Retrieved 25 February 2020, from https://surabaya.liputan6.com/read/4028297/risma-ingin-indonesia-bebas- sampah

Saadat, S., Rawtani, D. and Hussain, C.M., 2020. Environmental perspective of COVID 19. Science of The Total Environment, p.138870. 